\title{
Stocking density of threatened cat fish Heteropneustes fossilis (Bloch, 1792) in seasonal ponds of Rajshahi, Bangladesh
}

\author{
M. A. Samad ${ }^{1 *}$ and A. S. Bhuiyan ${ }^{2}$ \\ ${ }^{1}$ Department of Fisheries, University of Rajshahi, Rajshahi-6205, Bangladesh \\ ${ }^{2}$ Department of zoology, University of Rajshahi, Rajshahi-6205, Bangladesh
}

\begin{abstract}
An attempt was made to evaluate the effect of stocking density on the growth of Heteropneustes fossilis for a period of six months reared in earthen ponds at Rajshahi University Campus. H. fossilis fingerling were stocked at the rate of 320,280, 240/dec in treatment $\mathrm{T}_{1}, \mathrm{~T}_{2}$ and $\mathrm{T}_{3}$, respectively, The treatments had significant effects on the weight gain, length gain, ADG, SGR parameters among the treatments. Highest weight gain $(45.90 \mathrm{~g})$ was observed in $\mathrm{T}_{3}$ and lowest $(36.97 \mathrm{~g})$ in $\mathrm{T}_{1}$ Significant $(\mathrm{P}<0.05)$ highest yield was obtained in case of $\mathrm{T}_{2}$ and $\mathrm{T}_{3}$ and it was $2686.80 \mathrm{~kg} / \mathrm{ha}$ and $2343 \mathrm{~kg} / \mathrm{ha}$, respectively. Higher net benefits $(5,18519.91 \mathrm{TK} / \mathrm{ha})$ were obtained from treatment $\mathrm{T}_{2}$, than from treatments $\mathrm{T}_{1}$ and $\mathrm{T}_{3}$, water temperature, transparency, $\mathrm{pH}$ and dissolved oxygen did not differ significantly $(\mathrm{P}>0.05)$ among the treatments depicting the suitable range for fish culture. The plankton levels in all the treatments were found to be at optimum state. Final length, final weight and survival of fingerlings followed the same trends of weight gain. Cost benefit ratio was also highest (1:0.93) in $\mathrm{T}_{2}$ followed by $\mathrm{T}_{3}$ and $\mathrm{T}_{1}$. Overall, highest growth, fish yield survival (95.67\%) rate and net benefits of fingerlings were obtained at a density of $280 / \mathrm{dec}(69,160$ individuals/ha) in treatment $\mathrm{T}_{2}$ were recorded.
\end{abstract}

Keywords: Stocking density; Yield; Heteropneustes fossilis and cost benefit ratio

\section{Introduction}

The catfish, Heteropneustes fossilis (Bloch, 1792) is one of the best known cat fishes in Bangladesh. The flesh and skeleton of the fish supply a high percentage of protein and minerals like calcium, phosphorus, iron etc. (Basu and Gupta, 1939). It is found that the food value of $100 \mathrm{~g}$ flesh of H. fossilis contains protein $23 \mathrm{~g}$, fat $0.5 \mathrm{~g}$, calcium $0.67 \mathrm{~g}$ and phosphorus 0.65g (Siddiqui and Chaudhury, 1996). This type of composition is not found in any other fish groups available in fishery culture. So, the fish has a good nutritive value and physicians prescribe the fish for the convalescents and fast growing children.

The fish inhabits in both fresh and brackish waters but abundant in all types of freshwater bodies. It can be cultured in shallow ponds, canals, cemented cisterns, paddy fields and sewage waters. So commercial large-scale production of $H$. fossilis can play a vital role in the country economy. Polyculture failed to fulfill the demand of farmers and therefore they were looking for new species which could be cultured with high stocking density. Introduced African catfish $(C$. gariepinus) and Thai pangas were not accepted by consumers because of their predatory nature, black spots and poor taste in comparison with the local H. fossilis (Khan et al., 2005). So, the air-breathing indigenous stinging catfishes are the species which can fulfill the requirement of the people and farmers in Bangladesh. Catfishes are an important group of fishes in our country. According to Pal and Khan (1969), shing (Heteropneustes fossilis, Bloch) is a commercially important air breathing catfish which is one of the high ranking valuable fishes of Bangladesh. It is a highly popular, delicious table fish. Catfish is important due to its faster growth, easy culture system, disease resistant and tolerant to a wide range of environmental parameters. H. fossilis can survive at a reduced oxygen level (Stickney, 1979). Moreover, possession of accessory respiratory organs enable it to breathe in atmospheric air. The fish is very hardy and can be cultured in seasonal ponds of northern Bangladesh where carp culture is not possible. They require relatively small area for culture and can be stocked at higher density than any other species.

The stinging catfish ( $H$. fossilis) is commercially as well as aqua culturally an important species in many Asian countries (Akand et al., 1991). It occurs in all types of inland water bodies and can survive for a long time when kept in captivity even in a small quantity of water as it has a massive pair of sac-like structures as accessory respiratory organ (Das, 1972). Stocking density is an important parameter in fish culture operation in nursery and rearing ponds because, it has direct effects on growth, survival and production (Backiel and LeCern, 1978). For the development of culture technique of

\footnotetext{
*Corresponding author e-mail: samad1413@yahoo.com
} 
catfish (H. fossilis) stocking density on grow-out rearing might play a very important role.

The growth of fish is also dependent on the population density (Backiel and LeCren, 1978). Higher density may cause crowding effects and reduction in growth rate. So, it is necessary to determine a suitable stocking density for fry rearing of $H$.fossilis and $C$. batrachus.

Successful aquaculture requires not only careful selection of species, appropriate feeding and water quality management but also a great extent, the density to which the fishes are stocked as compared to the food ration and extent of management. Backiel and LeCren (1978) described stocking density as an important parameter in fish culture as the health, growth and survival of fishes depend upon this factor. Higher stocking density reduces the growth and survival rates during fish culture (Shugunan, 1997). Earlier very few studies were made on the biology of $H$. fossilis like Mia (1984) reported length-weight relationship, Das et al. (1989) calculated fecundity and Singh and Goswami (1989) studied the age and growth. Few published information is available on the effect of stocking density on growth and survival rate of $H$. fossilis. Considering the lack of information on these aspects, the present investigations were carried out to ascertain the optimum stocking density and enhanced yield of $H$.fossilis in Rajshahi, Bangladesh.

\section{Materials and methods}

\section{Location of the study area}

The experiment was performed in earthen ponds of $40.4 \mathrm{~m}^{2}$ in the hatchery complex, Department of Fisheries, University of Rajshahi for a period of six months .The ponds were similar in shape, depth, basin configuration including water supply facilities. The water depth was maintained around 1.2-1.5 m.
To maintain the water level and to keep the good water quality, water was added to the ponds at regular intervals using pump machine.

\section{Experimental design}

The experiment was designed in a completely randomized design with three treatments namely $\mathrm{T}_{1}, \mathrm{~T}_{2}$, and $\mathrm{T}_{3}$, each having three replications. Three different stocking densities were maintain in the experimental ponds as $320 / \mathrm{dec}(79,040$ individual/ha) in the $\mathrm{T}_{1}, 280 / \mathrm{dec}(69,160 \mathrm{individual} / \mathrm{ha})$ in the $\mathrm{T}_{2}$ and $240 / \mathrm{dec}\left(59,280\right.$ individual/ha) in the $\mathrm{T}_{3}$, respectively. The same size of $H$. fossilis fry were stocked to serve this purpose. Low cost indigenous feed (27\% protein level) provided to the fishes was same in this trial for each treatment, variation being only in stocking density as shown in Fig. 1.

\section{Pond preparation}

Control of undesirable species and aquatic weeds: Aquatic weeds and undesirable species were completely removed from all the experimental ponds by draining out of water. Lime (Calcium carbonate) was applied at the rate of $240 \mathrm{~kg} \mathrm{ha}^{-1}$. Lime was liquefied into an aluminum bucket and then applied by spreading homogenously in the ponds.

\section{Fertilization}

Ponds were fertilized with urea and triple super phosphate (TSP) each at a rate of $25 \mathrm{~kg} \mathrm{ha}^{-1}$ (Mazid, 2002) and cowdung at a rate of $1000 \mathrm{~kg} \mathrm{ha}^{-1}$ after three days of liming. TSP was applied after dissolving in plastic buckets for 10 to 12 hours before application. Fertilizers were applied by spreading methods.

\section{Collection of fishes}

The fingerlings $H$. fossilis were collected from a private

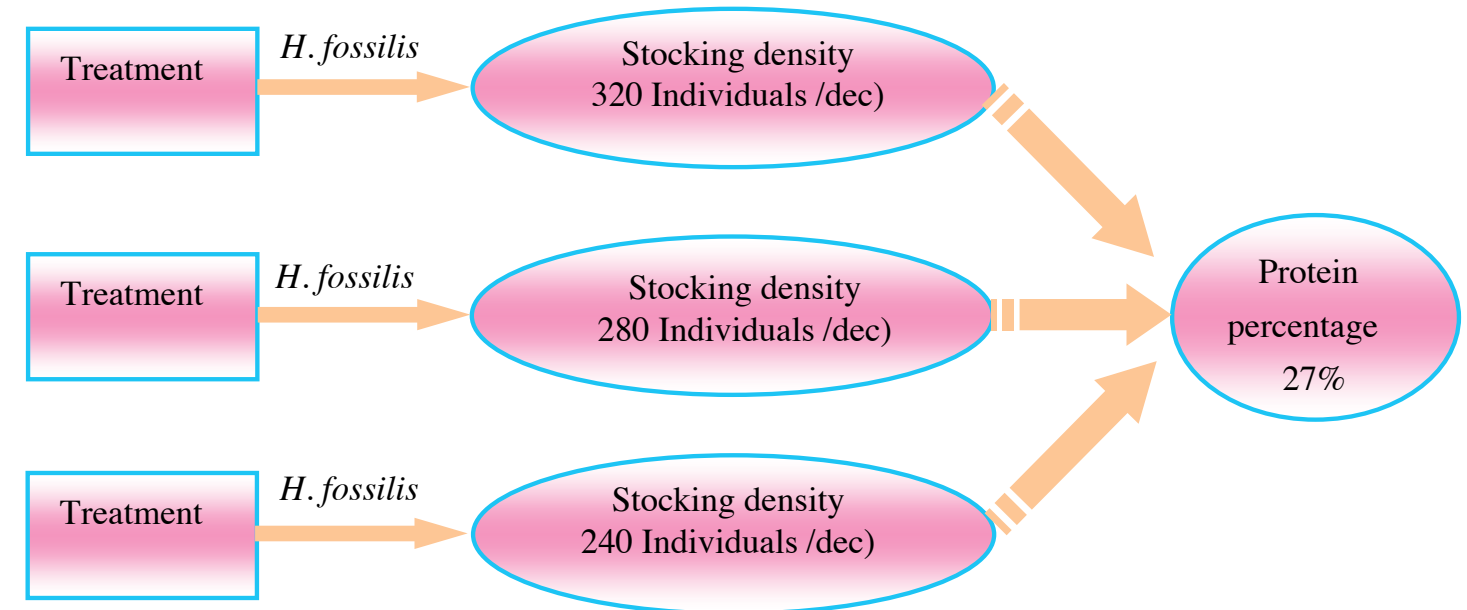

Fig. 1. Layout of the experiment on stocking density 
hatchery of the Madhupur Upazila of Tangail district in Bangladesh. The average weights of the fingerlings were $9.20 \pm 1.68 \mathrm{~g}$ Fingerlings were brought to the experimental site through plastic barrels with proper aeration. After completion of the first trial the fingerlings were again collected from the same place.

\section{Stocking}

Fingerlings were stocked at densities of 320/dec, 280/dec and $240 /$ dec in $T_{1}, T_{2}, T_{3}$, respectively. The fingerlings were transferred plastic bucket and released the experimental ponds. The length and weight of around $10 \%$ of all fingerlings of each pond were measured and recorded for estimating initial stocking biomass and to adjust initial feeding rate for fishes. The fishes were stout and naturally moving at the time of releasing in the ponds.

\section{Feeding of fishes}

The supplemental feed was given to $H$. fossilis at the rate of $5 \%$ of their body weight for proper growth of fishes at the beginning. The fishes were fed (containing $27 \%$ crude protein) daily at a rate of $5 \%$ of body weight for the first three months and $3 \%$ of body weight for next three months. Half of the required feed per day was supplied in the morning and rest half in the afternoon. The feeding was adjusted on the basis of fish weight. Feed requirements were calculated and adjusted after sampling of fishes once in a month. The composition of feed has been given in Table I. The ingredients were analyzed for their proximate composition and the results are shown in Tables-II \& III. The proximate composition of feed ingredients and experimental diets was analyzed according to the methods given in Association of Official Analytical Chemists (AOAC, 1980).

Table I. Composition of feed used in the experiments

\begin{tabular}{lc}
\hline Ingredients & Percentage \\
Fish meal & 22 \\
Mustard oil cake & 25 \\
Rice bran & 15 \\
Wheat bran & 28 \\
Wheat flour & 10 \\
\hline
\end{tabular}

\section{Growth sampling of fishes}

Fishes were sampled fortnightly using cast net to assess their growth and health condition. At least 10 fishes from each pond were taken to make assessment of growth trends and to readjust feeding rate. Length and weight of sampled fishes were measured using a measuring scale and digital electronic balance (OHAUS, MODEL no. CT-1200-S). Fishes were handled carefully to avoid stress during sampling.
Table II. Proximate composition of the feed ingredients used (\% dry matter basis)

\begin{tabular}{lcccccc}
\hline Ingredient & $\begin{array}{c}\text { Dry } \\
\text { matter }\end{array}$ & \multicolumn{2}{l}{ Protein Lipid } & Ash & Crude fibre & $\mathrm{NFE}^{\mathrm{a}}$ \\
Fish meal & 90.21 & 56.5 & 16.34 & 20.57 & 1.58 & 5.01 \\
Mustard oil cake & 91.65 & 31.5 & 10.85 & 8.94 & 10.53 & 38.18 \\
Rice bran & 89.32 & 12.50 & 14.76 & 12.45 & 15.23 & 45.06 \\
Wheat bran & 89.24 & 13.8 & 4.12 & 3.87 & 13.67 & 64.54 \\
Wheat flour & 88.74 & 16.5 & 5.4 & 10.3 & 11.4 & 56.4 \\
\hline
\end{tabular}

a Nitrogen free extract calculated as $100 \%$-(moisture+protein+ lipid + ash + crude fibre)

Table III. Analyzed proximate composition of the experimental diet (\% dry matter basis)

\begin{tabular}{ll}
\hline Components & Diet \\
Dry matter & 89.86 \\
Protein & 27.02 \\
Lipid & 11.26 \\
Ash & 10.83 \\
Crude fibre & 11.34 \\
NFE & 39.55 \\
Gross energy $(\mathrm{kj} / \mathrm{g}) 1$ & 17.422 \\
PE ratio $(\mathrm{mg} / \mathrm{kj}) 2$ & 15.5091 \\
\hline
\end{tabular}

${ }^{1}$ Gross energy was calculated according to Hasan et al., 1989; Tacon, 1990

${ }^{2}$ Protein to energy ratio in $\mathrm{mg}$ protein per $\mathrm{kJ}$ of gross energy

\section{Water quality monitoring}

Study of water quality variables: A number of water quality parameter such as temperature $\left({ }^{\circ} \mathrm{C}\right)$, transparency $(\mathrm{cm}), \mathrm{pH}$, dissolved oxygen $\left(\mathrm{mg} \mathrm{l}^{-1}\right)$ alkalinity, ammonia-nitrogen $(\mathrm{mg}$ $\mathrm{l}^{-1}$ ), were measured fortnightly at 9:00-10:00 am at the pond site to assess the physico-chemical condition of the pond.

Estimation of growth, survival, production and feed utilization

Twenty individuals from in each pond were sampled every ten days interval until they attained the marketing size. The growth performance of the individual were evaluated in terms of length and weight. Mean weight gain, average daily gain (ADG), specific growth rate (SGR), Food conversion factor (FCR), Survival rate (\%) and mean values( SD) for each parameter were computed. Average daily gain (ADG) and (\%) Survival were followed according to De silva (1989). SGR and FCR were calculated according to Brown (1957), Castell and Tiews (1980), Hepher (2009) 
respectively. After six month, the fishes were harvested by repeated netting, followed by drying the ponds. The individuals were counted and weighed. Survival and production (number.ha ${ }^{-1}$ ) of fishes were then calculated and compared among the treatment.

\section{Economic analysis}

Economic analysis was done to estimate the economic return in each treatment from the mono culture of $H$. fossilis. The cost of each ingredient was calculated on the basis of Rajshahi whole sale market price. The total cost of inputs was calculated and the economic return was determined by the differences between the total return (from the current market prices) and the total input cost. The cost in taka per unit yield (CPY) was calculated and was expressed as the cost in $\mathrm{Tk} / \mathrm{kg}$ of fishes produced.

\section{Statistical analysis}

The data were analyzed through one-way analysis of variance (ANOVA) using SPSS (Statistical Package for Social Science, version-11.5) followed by Duncan Multiple Range test to find out whether any significant difference existed among treatment means (Duncan, 1955). The level of significance was evaluated. The results are displayed as superscripts against each respective value.

\section{Results and discussion}

Water quality variables

The physico-chemical characteristics of water in earthen ponds where the fingerlings of $H$.fossilis were reared did not show significant variation (Table-IV). Suitable water quality parameters are prerequisite for a healthy aquatic environment and for production of the adequate fish food organisms.

Water transparency is a gross measure of pond productivity. It has inverse relationship with the abundance of plankton. Water transparency ranged from $18.10 \pm 0.12$ to $31.43 \pm 0.12$, $20.63 \pm 0.09$ to $27.63 \pm 0.30$ and $21.47 \pm 0.18$ to $28.17 \pm 0.07 \mathrm{~cm}$ in the treatments $\mathrm{T}_{1}, \mathrm{~T}_{2}$ and $\mathrm{T}_{3}$. Boyd (1990) recommended a transparency between 15 to $40 \mathrm{~cm}$ as appropriate for fish culture. Wahab et al. (1994) suggested that the transparency of productive water should be $40 \mathrm{~cm}$ or less. The mean values of secchi depth $(\mathrm{cm})$ were more or less similar among the treatments and those were 22.94 $\pm 2.02, \quad 23.63 \pm 0.99$ and $23.40 \pm 1.09 \mathrm{~cm}$, in treatments $\mathrm{T}_{1}, \mathrm{~T}_{2}$ and $\mathrm{T}_{3}$ respectively. Viveen et al. (1985) and Haque et al. (2005) recorded transparency $17-32$ and $20-35 \mathrm{~cm}$, respectively in catfish rearing ponds. The transparency values of different treatment in the present study indicated that the pond water seemed to be within the productive range for catfish culture.
Table IV. Variation in the mean $( \pm S E)$ values and ranges of water quality variables in different treatments during the study period

\begin{tabular}{lccc}
\hline Water quality & \multicolumn{3}{c}{ Treatments } \\
\cline { 2 - 4 } & $\mathrm{T}_{1}$ & $\mathrm{~T}_{2}$ & $\mathrm{~T}_{3}$ \\
\hline Transparency $(\mathrm{cm})$ & $22.94 \pm 2.02^{\mathrm{a}}$ & $23.63 \pm 0.99^{\mathrm{a}}$ & $23.40 \pm 1.09^{\mathrm{a}}$ \\
Water temperature $\left({ }^{\circ} \mathrm{C}\right)$ & $28.38 \pm 1.91^{\mathrm{a}}$ & $28.28 \pm 1.85^{\mathrm{a}}$ & $28.20 \pm 1.96^{\mathrm{a}}$ \\
$p \mathrm{H}$ & $7.17 \pm 0.04^{\mathrm{a}}$ & $7.22 \pm 0.04^{\mathrm{a}}$ & $7.24 \pm 0.03^{\mathrm{a}}$ \\
$\mathrm{DO}(\mathrm{mg} / \mathrm{l})$ & $5.54 \pm 0.10^{\mathrm{a}}$ & $5.52 \pm 0.16^{\mathrm{a}}$ & $5.50 \pm 0.14^{\mathrm{a}}$ \\
Alkalinity $(\mathrm{mg} / \mathrm{l})$ & $104.50 \pm 2.18^{\mathrm{a}}$ & $109.61 \pm 2.06^{\mathrm{a}}$ & $107.42 \pm 2.81^{\mathrm{a}}$ \\
$\mathrm{NH}_{3}-\mathrm{N}(\mathrm{mg} / \mathrm{l})$ & $0.0190 \pm 0.0023^{\mathrm{a}}$ & $0.0145 \pm 0.0002^{\mathrm{b}}$ & $0.0182 \pm 0.0005^{\mathrm{ab}}$ \\
\hline
\end{tabular}

Values in the same row having the same superscript are not significantly different $(\mathrm{P}>0.05)$

The maximum temperature $\left(32.67^{\circ} \mathrm{C}\right)$ was found in treatment $\mathrm{T}_{1}$ in July and that of minimum was $\left(19.27^{\circ} \mathrm{C}\right)$ in $\mathrm{T}_{3}$ in December. In Bangladesh, fish grows all the year round and there is no problem of very low temperature but sometimes extremely high temperature kills fishes especially in a shallow and turbid waterbody (Rahman et al., 1982). Quddus and Banerjee (1989) stated that the water temperature between $29^{\circ} \mathrm{C}$ and $32^{\circ} \mathrm{C}$ is suitable for the faster growth of fish spawn and aquatic organisms under natural conditions. Rahman (1992) found water temperature ranging from $25.5^{\circ} \mathrm{C}$ to $30.0^{\circ} \mathrm{C}$, which is favorable to fish culture. The mean values of temperature $\left({ }^{\circ} \mathrm{C}\right)$ were $28.38 \pm 1.91$, $28.28 \pm 1.85$ and $28.20 \pm 1.96^{\circ} \mathrm{C}$ in treatment $\mathrm{T}_{1}, \mathrm{~T}_{2}$ and $\mathrm{T}_{3}$ respectively, which were slightly high from the recommended suitable range. Britz and Hecht (1987) obtained higher growth rates between $25^{\circ} \mathrm{C}$ and $33^{\circ} \mathrm{C}$ the best was at $30^{\circ} \mathrm{C}$. However, Viveen et al. (1985), Sarkar et al. (2005) and Haque et al. (2005) recorded temperature $20-30^{\circ} \mathrm{C}, 28-31^{\circ} \mathrm{C}$ and $24-33.9^{\circ} \mathrm{C}$ respectively in catfish ponds.

Most water bodies have $p \mathrm{H}$ within the range of 6.5 to 8.5. The circum-neutral $p \mathrm{H}$ or slightly alkaline $p \mathrm{H}$ is most suitable for fish culture. An acidic $p \mathrm{H}$ reduces the growth rate, metabolic rate and other physiological activities of fish (Swingle, 1967). pH 6.5 to 9.0 is suitable for pond fish culture. More than 9.5 is unsuitable because free $\mathrm{CO}_{2}$ is not available in this situation. In the present experiment $p \mathrm{H}$ was around neutral to highly alkaline and it was due to local soil condition and heavy photosynthesis. The mean values of $p \mathrm{H}$ in treatments $\mathrm{T}_{1}, \mathrm{~T}_{2}$ and $\mathrm{T}_{3}$ were $7.17 \pm 0.04,7.22 \pm 0.04$ and $7.24 \pm 0.03$, respectively. The $p \mathrm{H}$ value recorded from the experiment agreed with the findings of Sarkar et al. (2005) and Haque et al. (2005). 
DO concentrations in water depend on many variables including temperature, sunlight, atmospheric pressure, salinity, plant life, and water turbulence. Fishes can survive at low levels of dissolved oxygen $\left(1 \mathrm{mg} \mathrm{l}^{-1}\right.$ or less) for few hours but not for long time. The DO concentration in the present study ranged from 3.95 to $6.25 \mathrm{mgl}^{-1}$. During the period of investigation, the DO content was found sometimes lower which caused for respiration of plankton, heavy temperature and other aquatic organisms, was also reported by Sharma et al. (1978). In the experiment the DO concentration ranged from 3.95 to $6.25 \mathrm{mg} / \mathrm{l}^{-1}$ which is fairly close with the findings of Sarkar et al. (2005) and Haque et al. (2005) who recorded the DO ranges from $3.87-5.85 \mathrm{mg} / \mathrm{l}^{-1}, 2.15-6.74 \mathrm{mg} / \mathrm{l}^{-1}$ and $1.10-6.80$ $\mathrm{mg} / \mathrm{l}^{-1}$, respectively under different treatments. The concentration of dissolved oxygen was fairly well as stocked fish did not show any sign of oxygen deficiency throughout the study period. According to Rahman (1992), DO content of a productive pond should be $5 \mathrm{mg} / \mathrm{l}$ or more. Banerjee (1967) and Bhuiyan (1970) reported 5.0 to $7.0 \mathrm{mg} / \mathrm{l}$ of DO content of water as fair or good in respect of productivity and water having DO less than $5 \mathrm{mg} / \mathrm{l}$ to be unproductive.

In alkaline waters essential nutrients were found in higher quantities and this was the most important reason for higher biological productivity in alkaline waters than in acidic waters. But highly alkaline condition is not favourable for biological production (Rahman, 1992). Total alkalinity may be several hundred $\mathrm{mg} \mathrm{l}^{-1}$ in natural waterbodies. In the present study mean values of total alkalinity were $104.50 \pm 2.18,109.61 \pm 2.06$ and $107.42 \pm 2.81 \mathrm{mg}^{-1}$ in treatment $\mathrm{T}_{1}, \mathrm{~T}_{2}$ and $\mathrm{T}_{3}$, respectively and The highest value of total alkalinity was $116.33 \mathrm{mg} \mathrm{l}^{-1}$ in $\mathrm{T}_{2}$ on December and the lowest value was $97.08 \mathrm{mg} \mathrm{l}^{-1}$ in $\mathrm{T}_{1}$ on October agreeing with the findings of Hossain et al. (2007), Sarkar et al. (2005),
Haque et al. (2005) recorded the values ranging from 81.25 to $147,87.33-114.0 \mathrm{mg} / \mathrm{l}^{-1}$ and $41.0-208.0 \mathrm{mg} / \mathrm{l}^{-1}$, respectively. According to Boyd (1982), total alkalinity should be more than $20 \mathrm{mg} \mathrm{l}^{-1}$ in natural fertilized ponds. Rath (2000) stated that calcareous water with alkalinity more than $50 \mathrm{ppm}$ was most productive. He also described the range of alkalinity 0-20 ppm as low productive, 20-40 ppm as medium productive and 40-90ppm as high productive. On the basis of findings it can be said that the total alkalinity recorded from the present study is within productive range. The highest value of ammonia-nitrogen $\left(0.0287 \mathrm{mg} \mathrm{l}^{-1}\right)$ was found in treatment $\mathrm{T}_{1}$ on 3 October and the lowest value was found 0.0137 in $\mathrm{T}_{2}$ on October. Chen (1988) found that lower than 1 $\mathrm{mg} \mathrm{l}^{-1}$ of $\mathrm{NH}_{3}$ gas content in pond was good for fish culture. However, he concluded that the permissible level was higher than the value of $0.012 \mathrm{mg} \mathrm{l}^{-1}$. The mean values of ammonia-nitrogen were $0.0190 \pm 0.0023,0.0145 \pm 0.0002$ and $0.0182 \pm 0.0005 \mathrm{mg} \mathrm{l}^{-1}$ in $\mathrm{T}_{1}, \mathrm{~T}_{2}$ and $\mathrm{T}_{3}$, respectively. Alam et al. (1997) recorded ammonia nitrogen value 0.2 to $0.4 \mathrm{mg} \mathrm{l}^{-1}$. So, in the present study ammonia-nitrogen value was suitable for catfish culture.

\section{Plankton population}

Boyd (1973) reported that fish excreta and uneaten portion of feed in catfish ponds supply large quantities of nutrients. Six planktonic groups were identified out of which 4 were from phytoplankton and 2 were from zooplankton. Similarly, Khan et al. (2005) recorded 4 group of phytoplankton and 2 groups of zooplankton. A total 29 genera of plankton, of which 20 were phytoplankton belonging to Bacillariophyceae (4), Chlorophyceae (9), Cyanophyceae (5) and Euglenophyceae (2) and 9 of zooplankton belonging to Rotifera (3) and Crustacea (6) were identified. More or less similar results were also obtained by Khan et al. (2005) and Dewan et al.

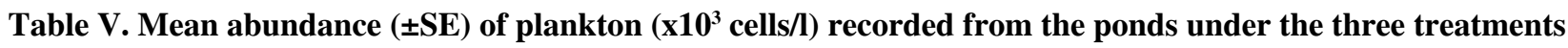

\begin{tabular}{lccc}
\hline & & Treatments & $\mathrm{T}_{3}$ \\
\cline { 2 - 4 } Groups & $\mathrm{T}_{1}$ & $\mathrm{~T}_{2}$ & $7.24 \pm 0.52^{\mathrm{a}}$ \\
\hline Bacillariophyceae & $8.33 \pm 0.73^{\mathrm{a}}$ & $7.58 \pm 0.80^{\mathrm{a}}$ & $33.71 \pm 1.14^{\mathrm{a}}$ \\
Chlorophyceae & $35.38 \pm 2.37^{\mathrm{a}}$ & $33.77 \pm 1.81^{\mathrm{a}}$ & $18.97 \pm 0.92^{\mathrm{a}}$ \\
Cyanophyceae & $21.22 \pm 1.64^{\mathrm{a}}$ & $18.90 \pm 1.25^{\mathrm{a}}$ & $2.83 \pm 0.41^{\mathrm{a}}$ \\
Euglenophyceae & $4.14 \pm 0.56^{\mathrm{a}}$ & $3.31 \pm 0.49^{\mathrm{a}}$ & $62.74 \pm 1.83^{\mathrm{a}}$ \\
Total Phytoplankton & $69.06 \pm 4.55^{\mathrm{a}}$ & $63.56 \pm 3.85^{\mathrm{a}}$ & 94.54 \\
Percentage & 94.20 & 93.14 & $1.58 \pm 0.22^{\mathrm{a}}$ \\
Rotifera & $1.91 \pm 0.23^{\mathrm{a}}$ & $2.27 \pm 0.29^{\mathrm{a}}$ & $2.04 \pm 0.32^{\mathrm{a}}$ \\
Crustacea & $2.34 \pm 0.26^{\mathrm{a}}$ & $2.41 \pm 0.37^{\mathrm{a}}$ & $3.62 \pm 0.43^{\mathrm{a}}$ \\
Total zooplankton & $4.25 \pm 0.26^{\mathrm{a}}$ & $4.68 \pm 0.50^{\mathrm{a}}$ & 5.45 \\
Percentage & 5.79 & 6.85 & $66.36 \pm 2.12^{\mathrm{a}}$ \\
Total plankton & $73.31 \pm 4.52^{\mathrm{a}}$ & $68.24 \pm 3.85^{\mathrm{a}}$ & \\
\hline
\end{tabular}

Means followed by same superscripts did not differ significantly at $5 \%$ level. 
(1991). Thus the recorded planktonic communities of the present experiment reflect the typical feature of plankton in tropical fish pond.

\section{Total plankton}

The mean abundance of total phytoplankton was $69.06 \pm 4.55 \times 10^{3} / 1$ in $\mathrm{T}_{1}, 63.56 \pm 3.85 \times 10^{3} / 1$ in $\mathrm{T}_{2}$ and $62.74 \pm 1.83 \times 10^{3} / 1$ in $\mathrm{T}_{3}$. Chlorophyceae was dominant among the phytoplankton group and Euglenophyceae was the least dominant group. The mean zooplankton concentration was $4.25 \pm 0.26,4.68 \pm 0.50$ and $3.62 \pm 0.43 \times 10^{3} / 1$ in treatment $\mathrm{T}_{1}, \mathrm{~T}_{2}$ and $\mathrm{T}_{3}$, respectively. There was no significant difference ( $>0.05)$ among the treatments. Crustacea was the dominant group among zooplankton. Statistical analyses showed no significant difference $(\mathrm{P}>0.05)$ in the mean abundance of total phytoplankton. Percentage composition of phytoplankton and zooplankton are shown in Table-5. Total phytoplankton and zooplankton comprised $94.20 \%$ and $5.79 \%$, respectively in $\mathrm{T}_{1}$ and $93.14 \%$ and $6.85 \%$, respectively in $\mathrm{T}_{2}, 94.54 \%$ and $5.45 \%$ $\mathrm{T}_{3}$. The mean value of total plankton was $73.31 \pm 4.52$, $68.24 \pm 3.85$ and $66.36 \pm 2.12 \times 10^{3} / 1$ in $\mathrm{T}_{1}, \mathrm{~T}_{2}$ and $\mathrm{T}_{3}$, respectively. The mean values showed no significant difference $(\mathrm{P}>0.05)$ among the treatments. The phytoplankton abundances were consistently higher than that of zooplankton. Similar results have also been recorded in various food fish and fry or fingerling rearing ponds (Wahab et al., 1994; Haque et al., 1998; Kohinoor et al., 1999; Chakraborty et al., 2003). The mean value of total plankton was ranged from $66.48 \times 10^{3} / 1$ to $72.15 \times 10^{3} / 1$ among the different treatments which is more or less similar to the findings of Mumtazuddin and Khalique (1987). Total plankton was not significantly $(\mathrm{P}>0.05)$ different among the treatments which might be due to the same stocking density and combination of the cultured species. The abundant planktonic population throughout the study period might be due to regular application of feed.

\section{Growth and production performances of $H$. fossilis}

Stocking density is recognized as an important factor which directly affects the growth, survival and production of fish (Backiel and LeCren, 1978). Generally highest stocking density results in reduction of growth and survival and increase in the food conversion ratio (FCR), and severe competition for food and space (Powell, 1972). During the study period, the average final weight was found to be $40.47 \pm 0.38,44.27 \pm 0.09$ and $45.90 \pm 0.42 \mathrm{~g}$ in $\mathrm{T}_{1}, \mathrm{~T}_{2}$ and $\mathrm{T}_{3}$ respectively (Table-6). Weight increments were ( $\mathrm{P}>0.05)$ statistically significant among the treatments. The highest growths in weight were observed in $\mathrm{T}_{3}(45.90 \mathrm{~g})$ where the fingerlings were stocked at the rate of 37050 individuals $/ \mathrm{ha}^{-1}$ and the lowest in $\mathrm{T}_{1}(40.47 \mathrm{~g})$ due to highest stocking densities
(61750 individuals $/ \mathrm{ha}^{-1}$ ). The average net weight gain in $\mathrm{T}_{1}, \mathrm{~T}_{2}$ and $\mathrm{T}_{3}$ were $36.97 \pm 0.38,40.77 \pm 0.09$ and $42.40 \pm 0.42 \mathrm{~g}$, respectively. Decline in fish growth rate and feed utilization with increasing levels of stocking densities has been observed in several studies (Vijayan and Leatherland, 1988; Suresh and Lin, 1992).

The average length increased in $\mathrm{T}_{1}, \mathrm{~T}_{2}$ and $\mathrm{T}_{3}$ from 18.5 \pm 0.79 , $18.77 \pm 1.01$ and $19.03 \pm 0.96 \mathrm{~cm}$, respectively. The highest growths in length were observed in $\mathrm{T}_{3}$ and lowest in $\mathrm{T}_{1}$. The average net length gain in $\mathrm{T}_{1}, \mathrm{~T}_{2}$ and $\mathrm{T}_{3}$ were 11.70 \pm 0.10 , $11.97 \pm 0.03,12.23 \pm 0.12 \mathrm{~cm}$, respectively. Singh and Goswami (1989) observed that the fish $H$. fossilis attained a length of 143-175 $\mathrm{mm}$ in 1st year, 195-209 $\mathrm{mm}$ in second year, and 223-235 $\mathrm{mm}$ in third year and 249-253 $\mathrm{mm}$ in the fourth year. The growth rate of $\mathrm{H}$. fossilis under the present study was within the range reported by Singh and Goswami (1989). The present result coincided with the findings of Kawamoto et al. (1957), Narejo et al. (2005), who achieved best growth at lower stocking densities. The specific growth rates $(\%$, per day) of $H$. fossilis were significantly influenced by the stocking density. The SGR value $(1.36 \pm 0.01)$ in $\mathrm{T}_{1}$ was very low and significantly higher $(\mathrm{P}<0.05)$ SGR $(1.43 \pm 0.01)$ were found in $T_{3}$. The average daily gain was found highest in $T_{3}$ $(0.24 \mathrm{~g})$ whereas, the lowest was found in $\mathrm{T}_{1}(0.21 \mathrm{~g})$, which were significantly $(\mathrm{P}>0.05)$ different among the treatments. Growth in terms of ADG and SGR of $H$. fossilis was higher $\mathrm{T}_{3}$ where the stocking density was low compared to those of $\mathrm{T}_{2}$ and $\mathrm{T}_{1}$, although same food was supplied in all treatments at an equal ratio. This phenomenon indicated that there was a low community feeling among the fishes which influenced them to take food properly. Similar observation was also noted by various authors; LeCren (1965), Powell (1972), Clay (1979), Das et al. (1992), Sahoo et al. (2002) who found maximum growth at low stocking densities. Whereas, Sarder and Mollah (1991) gave a different opinion in case of $P$. pangasius that growth rate increased at higher stocking densities ( 6 and $9 \mathrm{fish} / \mathrm{m}^{3}$ ) when compared with the lower one (3 fish $/ \mathrm{m}^{3}$ ). However, the reduced growth rate of higher stocking densities might be due to over crowed conditions or presence of water-borne, fish produced substances (Francis et al., 1974; Rose and Rose, 1975). Moreover, at higher stocking densities, presence of abundant food substances could produce a comparative interaction among the fish causing a stressful situation (Houde, 1975). The water quality in ponds of all the treatments was within the acceptable limit and the size and and the health of the fingerlings at stockings was good that furnished high survival rate.

Significant variation in the survival rate of $H$. fossilis was observed among different treatments. Highest survival rate $(95.67 \%)$ of $H$. fossilis in treatment- $\mathrm{T}_{2}$ appeared to be related to the low stocking density. Survival rate dropped to $(88.00 \%)$ 
in treatment $\mathrm{T}_{1}$ where the $H$.fossilis fishes were maintained at (79040 fry/ha). Therefore, stocking density-dependent effect was pronounced $(\mathrm{P}<0.05)$ on the survival rate of $H$. fossilis. The present study showed comparatively higher survival rates in lowest stocking densities. Similar observations were also made by Mollah (1985), Ita et al. (1989). The survival rate of present study also agreed with the findings of Samad et al. (2004) in H. fossilis ponds. Narejo et al. (2005) reported the highest survival rate of $H$. fossilis in lower stocking density.

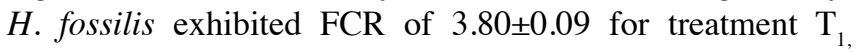

and the lowest in $\mathrm{T}_{1}$, which was significantly ( $\left.\mathrm{P}>0.05\right)$ different among the treatments. Cost and benefit ratio were significantly highest $(\mathrm{P}<0.05)$ in $\mathrm{T}_{2}(1: 0.93)$ and lowest in $\mathrm{T}_{1}$ (1:0.66) (Table-7). The cost of feed constituted the highest and showed positive relationship with the stocking density. The net profit was significantly highest $(\mathrm{P}<0.05)$ in $\mathrm{T}_{2}$ $(5,18519.91)$ and lowest in $T_{1}(4,02609.60 \mathrm{Tk} / \mathrm{ha})$. Haque et al. (2005) gained net profit which ranged from 1, 15,047 to 2, $71,178 \mathrm{Tk} / \mathrm{ha}$. The net profits obtained from the present study are much higher which might be due to uprising market price of $H$. fossilis. Considering the growth, survival, net

Table VI. Variation in the mean $( \pm \mathrm{SE})$ values of different growth parameters of $\boldsymbol{H}$. fossilis during the study period under treatments

\begin{tabular}{lccc}
\hline \multirow{2}{*}{ Growth parameters } & \multicolumn{3}{c}{ Treatments } \\
\cline { 2 - 4 } & \multicolumn{2}{c}{$\mathrm{T}_{2}$} & $\mathrm{~T}_{3}$ \\
\hline Initial weight $(\mathrm{g})$ & $3.50 \pm 0.00^{\mathrm{a}}$ & $3.50 \pm 0.00^{\mathrm{a}}$ & $3.50 \pm 0.00^{\mathrm{a}}$ \\
Final weight $(\mathrm{g})$ & $40.47 \pm 0.38^{\mathrm{c}}$ & $44.27 \pm 0.09^{\mathrm{b}}$ & $45.90 \pm 0.42^{\mathrm{a}}$ \\
Weight gain (g) & $36.97 \pm 0.38^{\mathrm{c}}$ & $40.77 \pm 0.09^{\mathrm{b}}$ & $42.40 \pm 0.42^{\mathrm{a}}$ \\
Length gain (cm) & $11.70 \pm 0.10^{\mathrm{b}}$ & $11.97 \pm 0.03^{\mathrm{ab}}$ & $12.23 \pm 0.12^{\mathrm{a}}$ \\
SGR & $1.36 \pm 0.01^{\mathrm{c}}$ & $1.41 \pm 0.02^{\mathrm{b}}$ & $1.43 \pm 0.01^{\mathrm{a}}$ \\
ADG & $0.21 \pm 0.003^{\mathrm{b}}$ & $0.23 \pm 0.002^{\mathrm{a}}$ & $0.24 \pm 0.003^{\mathrm{a}}$ \\
FCR & $3.80 \pm 0.09^{\mathrm{a}}$ & $3.93 \pm 0.02^{\mathrm{a}}$ & $3.77 \pm 0.04^{\mathrm{a}}$ \\
Survival rate (\%) & $88.00 \pm 0.58^{\mathrm{b}}$ & $95.67 \pm 0.33^{\mathrm{a}}$ & $93.00 \pm 1.53^{\mathrm{a}}$ \\
Fish yield (kg/ha/6 months) & $2538.37 \pm 44.57^{\mathrm{a}}$ & $2686.80 \pm 15.82^{\mathrm{a}}$ & $2343.00 \pm 62.68^{\mathrm{b}}$ \\
\hline
\end{tabular}

Means followed by same superscripts did not differ significantly at $5 \%$ level by DMRT

$3.93 \pm 0.02$ for treatment $\mathrm{T}_{2}$ and $3.77 \pm 0.04$ for treatment $\mathrm{T}_{3}$ under different stocking densities among the treatments. The highest $(3.93 \pm 0.02)$ FCR were observed with $\mathrm{T}_{2}$ while the lowest $(3.77 \pm 0.04)$ value was recorded with $\mathrm{T}_{3}$. The FCR values which were slightly higher than the values reported by Islam et al. (2002). De Silva and Davy (1992) stated that digestibility played an important role in lowering the FCR value by efficient utilization of food. The highest fish yield was recorded from $\mathrm{T}_{2}(2686.80 \mathrm{~kg} / \mathrm{ha} / 6$ months $)$ where the stocking densities were 69,160 individuals $/ \mathrm{ha}^{-1}$, and significantly lowest yield in $\mathrm{T}_{3}(2343.00 \mathrm{~kg} / \mathrm{ha})$, due to low stocking densities. The net production obtained from the present study is more or less similar with the author Haque et al. (2005) who recorded total production of fish ranging from 1398.08 to $2145 \mathrm{~kg} / \mathrm{ha}$ after six month rearing through providing commercial pellet feeds. The present result agrees with the finding of Mollah (1985) and Ita et al. (1989) who obtained higher production in higher density.

\section{Economics and profitability}

Similarly the net profit per unit of yield was the highest in $\mathrm{T}_{2}$ production and profit the results of the present study indicated that a stocking density of 69,160 individuals/ $\mathrm{h}^{-1}$ was suitable for fish culture and can earn more benefit. Considering the increase in growth rate, survival, net production and profit catfish $H$. fossilis of stocking density of the treatment $\mathrm{T}_{2}$ provided better result when compared with the higher densities. Thus a stocking density of 69,160 individuals/ $\mathrm{h}^{-1}$ could be recommended to culture in earthen ponds in Rajshahi region.

\section{Conclusion}

Considering increase in growth rate, survival, net production and profit of $H$. fossilis, the stocking density of the treatment $\mathrm{T}_{2}$ produced better result when compared to the higher densities. Thus a stocking density of 69160 individuals/ $\mathrm{h}^{-1}$ (280/dec.) could be recommended to culture in earthen ponds in Rajshahi region. Stinging cat fish is an important and threatened high valued fish species which will definitely play an important role for livelihood upliftment of the rural fish farmers. So, the farmers may come forward for adapting $H$. fossilis culture techniques from which they will be able to make more profit than other fish species. 
Table VII. Input cost and economic return in $H$. fossilis for six months in the ponds under three different treatments

\begin{tabular}{lccc}
\hline \multirow{2}{*}{ Economical parameters } & \multicolumn{3}{c}{ Treatments } \\
\cline { 2 - 4 } & $\mathrm{T}_{1}$ & $\mathrm{~T}_{2}$ & $\mathrm{~T}_{3}$ \\
\hline Investment & $237120.00^{\mathrm{a}}$ & $207480.00^{\mathrm{b}}$ & $177840.00^{\mathrm{c}}$ \\
Cost of seed (Tk./ha) & $( \pm 0.00)$ & $( \pm 0.00)$ & $( \pm 0.00)$ \\
& $332869.06^{\mathrm{a}}$ & $309914.26^{\mathrm{a}}$ & $284597.35^{\mathrm{b}}$ \\
Feed cost (Tk/ha) & $( \pm 11505.31)$ & $( \pm 777.49)$ & $( \pm 1025.48)$ \\
& $42749.18^{\mathrm{a}}$ & $38804.57^{\mathrm{b}}$ & $34682.80^{\mathrm{c}}$ \\
Operational cost (Tk/ha) & $( \pm 862.90)$ & $( \pm 58.31)$ & $( \pm 76.91)$ \\
& $612738.24^{\mathrm{a}}$ & $556198.83^{\mathrm{b}}$ & $497120.15^{\mathrm{c}}$ \\
Total Cost(Tk/ha) & $( \pm 12368.20)$ & $( \pm 835.80)$ & $( \pm 1102.39)$ \\
& $1015347.84^{\mathrm{a}}$ & $1074718.74^{\mathrm{a}}$ & $929455.07^{\mathrm{b}}$ \\
Total return (Tk/ha) & $( \pm 17828.93)$ & $( \pm 6326.35)$ & $( \pm 24867.11)$ \\
& $158.60^{\mathrm{c}}$ & $192.98^{\mathrm{a}}$ & $184.52 \mathrm{~b}$ \\
Net Profit per unit of yield (Tk/kg) & $( \pm 0.55)$ & $( \pm 0.39)$ & $( \pm 0.64)$ \\
& $402609.60^{\mathrm{b}}$ & $518519.91^{\mathrm{a}}$ & $432334.92^{\mathrm{b}}$ \\
Net Profit (Tk/ha) & $( \pm 6451.42)$ & $( \pm 6950.81)$ & $( \pm 24823.80)$ \\
& $0.66 \mathrm{~b}$ & $0.93^{\mathrm{a}}$ & $0.87^{\mathrm{a}}$ \\
CBR & $( \pm 0.01)$ & $( \pm 0.01)$ & $( \pm 0.05)$ \\
\hline
\end{tabular}

Mean values in the same row having same superscripts are not significantly different

Seed cost $=3.00$, Feed cost $=$ Tk 30/-, Market price of $H$. fossilis $\mathrm{T} 1=400 /-, \mathrm{T} 2=425 /-$, and $\mathrm{T} 3=475 /-$

Price is related with size and weight of $H$.fossilis, Leasing cost of pond is not included.

Operational cost is considered as $7 \%$ of the total cost.

\section{Acknowledgements}

The authors are thankful to Department of Fisheries, University of Rajshahi, Bangladesh for the facility and infrastructure provided to carry out this research work.

\section{References}

Akand AM, Hasan MR. and Habib MBA (1991), Utilization of carbohydrate and lapis as dietary energy source by stinging catfish, Heteropneustes fossilis (Bloch) In: Fish nutrition research in Asia, Ed. De Silva SS, Proc. $4^{\text {th }}$ Asian fish nutrition workshop, Asian Fisheries Society special publication, Asian Fish Soci Manila, Philippines, pp 93-100.

Alam MJ, Hoq ME, Jahan DA and Mazid MA (1997), Nursery rearing of Macrobrachium rosenbergii (de Man) using hapa-nets: effects of stocking density, Bangladesh J. Fish. Res. 1(1): 09-16.

AOAC (1980), Official methods of analysis of the association of official analytical chemists, Ed. Horwitzw W, 13 ${ }^{\text {th }}$ Ed., Washington DC, p 1018.
Backiel T and LeCren ED (1978), Some density relationship for fish population parameters In: Ecology of freshwater fish production, Ed. Gerking SD, Blackwell Scientific Publication, Oxford, pp 279-302.

Banerjea RK (1976), Poultry droppings and it manorial potentiality in Aquaculture, J. Inland Fish. Soc. India 11(1): 98-108.

Banerjee SM (1967), Water quality and soil conditions of fishponds in some states at India in relation to fish production, Indian J. Fish. 14: 115-155.

Basu KP and Gupta K (1939), Biological value of protein of some species of Bengal fish by nitrogen balance and growth methods, J. Indian Chem. Soc. Calcutta, p 543-548

Bhuyan BR (1970), Physico-chemical qualities of water of some ancient tanks in Sibsagar, Assam, Environmental Health 12: 129-134.

Boyd CE (1973), Summer algal communities and primary productivity in fish ponds, Hydrobiologia 40: 357-390p.

Boyd CE (1982), Water quality management for pond fish 
culture, Elsevier Science Publishers B.V., 1000 Amsterdam, The Netherlands, p 318.

Boyd CE (1990), Water quality in ponds for aquaculture. Birmingham Publishing Co., Birmingham, Alabama, USA, p 477.

Britz PJ and Hecht T (1987), Temperature preferences and optimum temperature for growth of African sharp tooth catfish (Clarias gariepinus) larvae and post larvae, Aquaculture 63: 205-214.

Brown ME (1957), Experimental studies on growth In: The physiology of fishes, $1^{\text {st }}$ Ed., Academic Press, New York, p 447.

Castell JD and Tiews K (1980), Report of the EIFAC, IUNS and ICES Working Group on the Standardization of Methodology in Fish Nutrition Research, Hamburg, Federal Republic of Germany.

Chakraborty BK, Miah MI, Mirza MJA and Habib MAB (2003), Rearing and nursing of local sarpunti, Puntius sarana (Hamilton) at different stocking densities, Pak. J. Biol. Sci. 6(9): 797-800.

Chen IC (1988), Aquaculture in Taiwan, Fishing News Book, London, p 273.

Clay D (1979), Population biology, growth and feeding of the African Catfish, Clarias gariepinus, with special reference to juveniles and their importance in fish culture, Arch. Hydrobiol. 87(4): 453-482.

Das M, Islam AM and Mughal GU (1992), Induced breeding and fry rearing of catfish Clarias batrachus (Linn.) Bangladesh J. Fish. 20(1): 87-95.

Das BK (1972), The bionomics of certain air-breathing fishes of India together with an account of the development of their air-breathing organs, Phil. Trans. 216: 183-219.

De Silva SS (1989), Reducing feed costs in semi-intensive aquaculture systems in the tropics, NAGA 12: 6-7.

De Silva SS and Davy FB (1992), Fish nutrition research for semi-intensive culture system in Asia, Asia Fisheries Science 5: 129-144.

Dewan S, Wahab MA, Beveridge MCM, Rahman MH and Sarker BK (1991), Food selection selectivity and dietary overlap among planktivorous Chinese and Indian major carps fry and fingerlings grown in extensively managed, rain- fed ponds in Bangladesh, Aquacult. and Fish Management 22: 277-294.

Duncan DB (1955), Multiple range and multiple ' $F$ ' Tests, Biometrics 11: 1-42.

Francis AA and Smith F and Pfuderer P (1974), A heart-rate bioassay for crowding factors in goldfish, Prog. Fish-Cult. 105(3-4): 281-296.
Haque F, Khan S, Ferdoushi Z, Haque MM and Sarkar MRU (2005), Nutrient loading and microalgal proliferation in pangasid catfish, Pangasius hypophthalmus culture ponds, Bangladesh. J. Fish. 29(1-2): 55-62.

Haque MS, Wahab MA, Wahid MI and Haq MS (1998), Impacts of a Thai silver barb (Puntius gonionotus, Bleeker) inclusion in the polyculture of carps. Bangladesh J. Fish. Res. 2: 15-22.

Hasan MR, Alam MGM and Islam MA (1989), Evaluation of some indigenous ingredient as dietary protein sources for the cat fish (Clarias batrachus, Linnaeus) fry In: Aquaculture research in Asia: Management Techniques and Nutrition, Eds. Huisman EA, Zonneveld $\mathrm{N}$ and Bouwmans AHM, Pudoc Press, Wageningen, pp 125-137.

Hepher B (2009), Nutrition of pond Fishes, Cambridge University Press, UK, pp 4-14.

Houde ED (1975), Effect of stocking density and food density on survival, growth and yield of laboratory reared larvae of sea bream, Archosargus rhombidales L. (Sparidae), Journal of Fisheries Biology 7: 115-127.

Islam MS, Dewan S, Hussain MG, Hossain MA and Mazid MA (2002), Feed utilization and wastage in semi-intensive pond culture of mahseer, Tor putitora (Ham.), Bangladesh J. Fish. Res. 6: 1-9.

Ita EO, Madu CT, Omorinkoba WS and Pandogari A (1989), Preliminary estimator of the survival rate of Clarias angullaris fry under out door hatchery management system, Annu. Rep. Natl. Inst. Fish. Res. Nigeria, pp 88-94.

Kawamoto NY, Inoye Y and Nakanishi S (1957), Studies on the effects by the pond areas and densities of fish in the water upon the growth rate of carp (Cyprinus carpio L). Rep. Faculty Fish. Prefect. Univ. Mic. 2: 437-447.

Khan MA, Jafri AK and Chadha NK (2005), Effects of varying dietary protein levels on growth, reproductive performance, body and egg composition of rohu, Labeo rohita (Hamilton), Aquac. Nutr. 11: 11-17.

Kohinoor AHM, Islam MS, Begum N and Hussain MG (1999), Production of Thi sharpunti (Puntius gonionotus Bleeker) in polyculture with carps using low cost feed, Bangladesh J. Fish. Res. 21: 77-83.

LeCren ED (1965), Some factors regulating the size of population of Freshwater, Mitt. int. Verein. Theoro Agew. Limnol. 13: 88-105.

Mazid MA (2002), Development of Fisheries in Bangladesh, Plans and strategies for income generation and poverty alleviation, Dhaka, Bangladesh, p 176.

Mia GK (1984), Length-weight relationship and condition factor in the air-breathing catfish, Heteropneustes fossilis (Bloch), Bangladesh J. Zool. 12(1): 49-52. 
Mollah MFA (1985), Effects of stocking density and water depth on the growth and survival of freshwater catfish (Clarias macrocephalus Gunther) Larvae, Indian J. Fish. 32(1): 1-17.

Mumtazuddin M and Khalique MA (1987), Observation on the growth potential of carp hatchlings in relation to fertilization and supplemental feeding, Bangladesh $J$. Fish. Res. 2-5: 83-90.

Narejo NT, Salam MA, Sabur MA and Rahmatullah SM (2005), Effect of stocking density on growth and survival of indigenous catfish, Heteropneustes fossilis (Bloch) Reared in Cemented Cistern Fed on Formulated Feed, Pakistan J. Zool. 37(1): 49-52.

Pal RN and Khan H A (1969), Breeding and development of Heteropneustes fossilis (Bloch), Proc. Indian Sci. Congr. 56(3): 543.

Powel MR (1972), Cage and raeeway culture of striped bass in brackish water in Alabama, Proceedings of the $26^{\text {th }}$ Annual Conference of the Southeastern Association of Game and Fish Commissions, p 65-553.

Quddus MMA and Banerjee AK (1989), Diurnal variations in the physico-chemical parameter of nursery pond, Bangladesh J. Aquaculture 11-13: 47-51.

Rahman AKA (2005), Freshwater Fishes of Bangladesh, $2^{\text {nd }}$ Ed. Zoological Society of Bangladesh, Department of Zoology, University of Dhaka, Dhaka-1000, pp 1-263.

Rahman MA, Geyasuddin S and Chakraborty SC (1982), Formulation of quality fish feed from indigenous raw materials and its effect on the growth of catfish (Heteropneustes fossilis), Bangladesh J. Fish. 2-5(1-2): 65-72.

Rahman MS (1992), Water quality management in aquaculture, BRAC PRAKASHANA, 66 Mohakhali, Dhaka-1212, Bangladesh, p 75.

Rath RK (2000), Freshwater aquaculture, $2^{\text {nd }}$ scientific publishers, Jodhpur, India, p 445.

Ricker WE (1973), Linear regression in fisheries research, $J$. Fish. Res. Board Can. 30: 409-434.

Ricker WE (1975), Computation and Interpretation of Biological Statistics of Fish Populations, Bulletin of the Fisheries Research Board of Canada, No 119: 1-382.

Rose SM and Rose CF (1975), The control of growth and reproduction in freshwater organisms by specific products, Mitt. Int. Vercin. Theor. Agrew. Limnol. 13: 21.

Sahoo SK, Giri SS and Sahu AK (2002), Effect of density on growth and survival of Clarias batrachus fry during hatchery rearing In: Proc. $6^{\text {th }}$ Indian Fisheries Forum, CIFE, Mumbai, pp 17-20.

Samad MA, Isla MA, Khaleque MA, Amin MR and Alam MS (2004), Fry rearing and culture of indigenous catfish,
Shingi (Heteropneustes fossilis Bloch, 1794), Progress. Agric. 15(1): 121-131.

Sarder MRI and Mollah MFA (1991), Stocking density effects on Pangus, Pangasius pangasius (Hamilton) growth in net cages, Bangladesh J. Fish. 14 (1-2): 21-29.

Sarkar MRU, Khan S and Haque MM (2005), Production and economic return in pangasid catfish (Pangasius hypophthalmus) monoculture and polyculture with silver carp (Hypophthalmichthys molitrix) in farmers' ponds, B. J.Fish. 9(2): 111-120.

Sharma K, Goel PK and Gopal P (1978), Limnological studies of polluted fresh waters. I. Physico-chemical characteristics, Int. J. Ecol. Environ. Sci. 4: 89-105.

Shugunan VV (1997), Fisheries management of small water bodies in seven countries in Africa, Asia and Latin America, FAO Fisheries Circular No. 933, Rome, FAO, p 149.

Siddiqui K and Choudhury SN (1996), A manual on pond pisciculture, Published by the National Institute of Local Government, Agargaon, Dhaka, p 606.

Singh MPK and Goswani UC (1989), Studies on the age and growth of and air-breathing catfish, Heteropneustes fossilis (Bloch.), J. Inland Fish Soc. India 21: 17-24.

Stickney R (1979), Principles of Aquaculture, John Willey and sons, New York, Manchester, Brisbane, Toronto, p 375.

Suresh AV and Lin CK (1992), Effect of stocking density on water quality and production of red tilapia in a recirculated water system, Aqua. Eng. 11: 1-22.

Swingle HS (1967), Standardization of chemical analysis for water and pond muds, FAO fish report 4(a): pp 397-421.

Tacon AGJ (1990), Standard methods for the nutrition and feeding of farmed fish and shrimp, Washington DC, Argent Laboratories press, p 454.

Vijayan MM and Leatherland JF (1988), Effect of stocking density on the growth and stress-response in Brook Charr, Salvelinus fantinalis. Aquaculture 75: 159-170.

Viveen WJ, Richter CJ, Janssen JA, van Oordt P G and Huisman EA (1985), Practical manual for the culture of the African catfish (Clarias gariepinus), Dept. of Fish Culture and Fisheries, Agricultural University of Wageningen, the Netherlands, p 121.

Wahab MA, Ahmed ZF, Haq MS and Begum M (1994), Compatibility of silver carp in the polyculture of cyprinid fishes, Prog. Agric. 5(2): 221-227.

Received: 03 April 2017; Revised: 24 May 2017;

Accepted: 29 May 2017. 